\title{
Basic education teachers' concept of effective teaching: Inputs to teacher education curriculum in the Philippines
}

\author{
Abulon, Edna Luz Raymundo $\varangle$ \\ Philippine Normal University, Philippines (non_eds@yahoo.com) \\ Accepted: 16 March 2014 \\ ISSN: 2243-7703 \\ Online ISSN: 2243-7711 \\ OPEN ACCESS
}

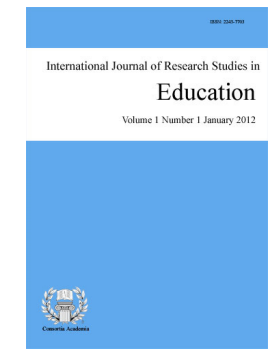

\section{Abstract}

Conceptual understanding about effective teaching was explored among basic education teachers from public schools situated in the City of Manila. Teacher-respondents from kindergarten, elementary and high school levels $(\mathrm{N}=355)$ were asked to respond to a questionnaire with open-ended items from which qualitative research data were gathered. Thematic analysis served as the springboard for the identification of underlying themes and core related ideas as guided by four 'a priori' major categories embodied in the study's conceptual framework. Five major themes ultimately emerged to characterize the conglomeration of conceptions of effective teaching from personality-based dispositions, teaching competence traits, content mastery and expertise, pedagogical knowledge and extension of the self. The study concluded that there was no single, predominant factor or heuristic that was identified upon which effective teaching is largely and/or solely contingent. Instead, effective teaching was viewed as a confluence of various dispositions, traits, knowledge, and skill sets. A new framework was crystallized to depict the five critical factors of effective teaching in the basic education. The resulting typical and variant core ideas of what effective teaching is, served as useful benchmarks in curriculum planning and re-designing of pre-service teacher education programs administered in teacher education institutions in the Philippines. Some implications of the findings to in-service teacher education were also established in the study.

Keywords: teachers' conceptions; effective teaching; basic education; qualitative research 


\section{Basic education teachers' concept of effective teaching: Inputs to teacher education curriculum in the Philippines}

\section{Introduction}

The Philippine government has joined the global commitment referred to as Education for All (EFA) which was first launched in Thailand in 1990 to deliver the many benefits of education to every citizen in every society. Locally, the EFA program is referred to as the Philippine Education for All (EFA) 2015 program which is spearheaded by the Department of Education. It aims to provide greater access to basic education for every Filipino by 2015 , as well as to raise the quality of basic education.

At the core of this effort of the Philippine Government through the Department of Education towards the improvement of the quality of basic education is an investigation on teachers' conceptions of effective teaching. This is because teachers' conceptions and beliefs on what precisely constitutes effective teaching have a direct and immense influence on their own teaching practices which will eventually translate into how well children learn inside the classroom. The conceptions of teachers themselves generated in this study may not paint a complete picture of what is effective teaching. Nonetheless, they provide a very rich data which can serve as basis for policy formulation and/or refinement of the existing policies on teacher education in the Philippines.

The importance of exploring the kindergarten, elementary and secondary school teachers' concept of effective teaching cannot be underestimated. For a majority of the Filipino youth, these three stages of education represent crucial exposures into formal education. As such, any positive and/or negative experiences with a teacher will inevitably create a huge impact on how the students will perceive the learning environment. This influence is not merely confined to the grade level in which the student interacts with a given teacher; but, more critically, such an influence by a teacher extends well beyond the confines of the classroom and may eventually shape how a young, impressionable mind values the lifelong process of education. Indeed, it is not a far-fetched idea that facility at learning in the elementary and high school levels generally translate into facility at learning in the tertiary school level. Likewise, learning difficulties that start in these basic levels of education generally translate into learning difficulties in the tertiary school level.

In view of this, the aim of this research was to investigate the kindergarten, the elementary school and high school teachers' concepts of effective teaching. Utilizing a qualitative research approach, this study explored the major themes as well as core ideas on the nature of effective teaching as provided by the teacher respondents themselves. These themes and ideas were categorized. The resulting classifications served as salient points that may form the basis for recommending strategies which may be utilized by teachers, school administrators, and policy-makers within the education sector.

\section{Review of Related Literature}

In virtually every learning situation, the teacher stands as an important variable in student achievement. Moreover, the influence of teachers generally transcends the confines of the classroom. Indeed, effective teachers tend to shape the students' cognitive development as well as their lifelong quest for personal growth and development. As such, it is imperative for researchers to identify the characteristics of effective teachers, especially in the hope of incorporating and reinforcing these characteristics into the roster of teachers. This applies to both the experienced teachers and those who are still undergoing teacher training programs. Indeed, the studies included in this review summarize empirical data acquired from exemplary teachers themselves who recounted their own characteristics which were confirmed by stakeholders' (i.e., students and school administrators) evaluations of effective teachers. This gives the following literature review a well-rounded and comprehensive panorama. 
Basic education teachers' concept of effective teaching: Inputs to teacher education curriculum

Charting some of the classic studies on the conceptions of essential characteristics of good teachers showed traits ranging from love, patience, trust (Bollnow, 1960) to enthusiastic, alert, have a sense of humor, fair, patient, understanding (Ryans, 1960). Equally, labeling of effective teachers cover personal-social; emotional; physical; and moral and spiritual qualities (Wynn 1960). Teaching skills and procedures related to effective teaching were also studied. The study of Gage (1972) found out that effective teachers have a high level of cognitive organization, deliver lessons from memory, while Bell (1962) noted direct relevant use of time, encouraging class discussion, and showing implications of learning to life situations were evidences of effective teaching.

For the last four decades, several measures of effectiveness were used like that of Klausmeier (1971) who posited that teacher effectiveness should be assessed using three types of criteria: process, product and presage. Product pertains to what is learned by the students. Process lies on what the teacher does in teaching while presage refers to teachers' characteristics such as academic background, personal appearance and intellectual ability. It cannot be disputed that all teachers bring their dispositions and personalities, such as their cognitive, behavioral, and affective traits, into the classroom, every day. Indeed, as noted by Kirchner (2008), teachers' dispositions and personality traits do tend to "impact their career choice, learning in a teacher preparation program, use of teaching strategies and methods, relationships with students, and ability to cope with change. "Therefore, these dispositional characteristics and personality traits, taken collectively, are therefore important criteria in determining teaching effectiveness" (Kirchner, 2008).

With respect to the Big Five Personality Dimensions, primary school teachers who scored high on the "neuroticism personality index" were also the ones who had higher levels of personal accomplishment in teaching (that is, they were the effective teachers). However, high neuroticism was also found to lead to greater vulnerability to burnout (Kokkinos, 2007). These findings suggest two things: first, personality traits tend to interact significantly with work-related stress of primary school teachers and that effective teachers are the ones who are more susceptible to burnout (Kokkinos, 2007, p. 230). Related to this, less effective teachers (i.e., those in the lowest quartile) were also found to be less socially mature, less receptive to criticism, less likely to incorporate criticism to teaching changes, and scored the least on their generative pre-active and interactive teaching scores (Kourilsky, Esfandiari, \& Wittrock, 1993).

Teachers have also identified specific personality traits that have a positive impact on both their classroom management skills as well as to their commitment to students' overall well-being. These are: "being organized, structured, personally satisfied, ethical, moralistic, just, creative, nonconforming, and personifying the work ethic" (Pajak \& Blasé, 1989). Bustos-Orosa (2008) also adds self-awareness, confidence, and a good sense of humor to this list. Intuitively, teachers are able to develop patterns of teaching behavior that are characteristic of their instructional practice (Gonzalez-Thompson, 1984). However, there are also instances wherein patterns of teaching behavior serve as manifestations of consciously held notions, beliefs, and preferences that act as 'driving forces' in shaping the teacher's behavior. In other cases, the driving forces may be unconsciously held beliefs or intuitions that have evolved out of the teacher's experience (Gonzalez - Thompson, 1984, p. 105). Indeed, researchers have observed that teachers' beliefs have an immense influence on classroom instruction, especially in mathematics, reading, and science (Ertmer, 2005).

Moreover, recent studies have shown that, with regard to the behavioral component of teaching competencies, effective primary school teachers did more to establish routines and procedures at the start of the school year (Bohn, Roehrig, \& Pressley, 2004). Indeed, compared to less effective teachers, highly effective teachers offered more engaging activities, introduced reading and writing in a more enthusiastic manner, indicated higher expectations, praised specific accomplishments of their students, pointed out when specific students were behaving in a praiseworthy fashion, and encouraged student self-regulation. Moreover, it should be emphasized that these routines and procedures were already present even as early as the first day of classes thus suggesting that these skills and competencies have been embedded in the teaching repertoire of effective teachers (Bohn, Roehrig, \& Pressley, 2004). 
Another critical interpersonal competency of effective teaching is "teacher confirmation behavior". This is defined as the "process by which teachers communicate to students that those students are valuable, significant individuals" (Ellis, 2004, p. 2). According to Ellis (2000, p. 3), teacher confirmation is a "strong, significant predictor of learning... explaining 30 percent of the variance in affective learning and 18 percent of the variance in cognitive learning." Effective classroom instruction has been identified as the critical variable for fostering student achievement, especially in the elementary and high school levels. As noted by Morine-Dershimer and Kent (2002), "whereas curriculum knowledge is fed by both the teacher's content knowledge and knowledge of goals/assessment procedures, pedagogical knowledge is fed by both the teacher's knowledge of learners/learning and knowledge of goals/assessment procedures."

In addition to the above, Snow et al. (1991) also noted that effective teachers used a wider variety of materials, instructional methods, and classroom organizational plans (e.g., open classrooms, three-group organizations). However, faced with the rapid pace of technology, the traditional pedagogical competencies of teachers, such as their facility at providing appropriate visual aids and engaging the students' different senses during learning, are no longer enough in capturing students' attention. In this regard, teachers must keep abreast with the technological advancements and take advantage of these whenever possible. The aforementioned studies have direct bearing on the current study as they dealt with how effective teaching should be delivered. The main contribution of the current study, however, lies on its intention to focus on the basic education teachers in the Philippine setting.

\subsection{Conceptual Framework}

The research model utilized in the present study is based on the four emergent themes which Bustos-Orosa (2008) developed in her research on teachers' conceptions of good teaching with focus on teaching from elementary to college. These are: (1) personality-based dispositions, (2) teaching competency traits, (3) content mastery and expertise, and (4) pedagogical knowledge. Using the outcomes of the present research, this investigator attempted to expand Bustos-Orosa's (2008) model, thereby enabling the construction of a more comprehensive framework that is nonetheless is geared towards addressing the demands and fully applying the unique characteristics of effective teaching at the basic education level. Thus, the initial framework on which the study was based is shown in Figure 1.

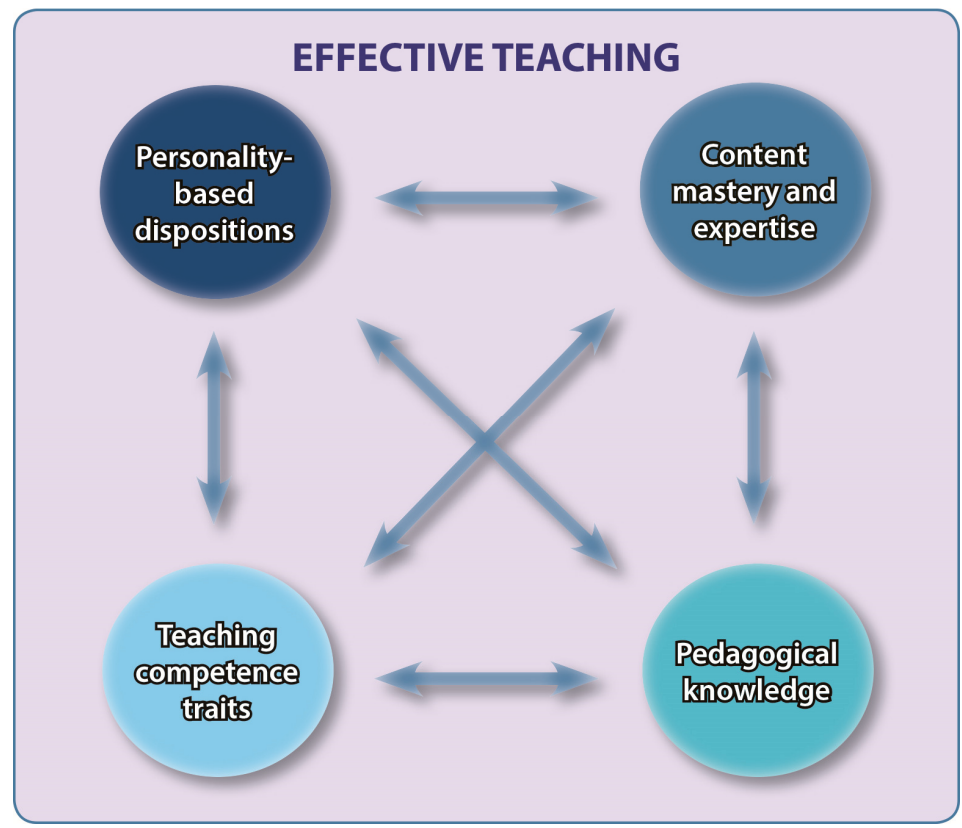

Figure 1.Conceptual Framework of Effective Teaching (adapted from Bustos-Orosa's [2008] Model of Critical Factors in Good Teaching, p. 170) 


\subsection{Research Problem}

This study aimed to address the conceptual understanding of basic education teachers in the City of Manila, about effective teaching. Specifically, the study attempted to answer the following research questions:

$>\quad$ What are the personality-based dispositions of teachers related to effective teaching?

$>\quad$ What competencies and expertise are related to effective teaching?

$>\quad$ What pedagogical knowledge and skills are related to effective teaching?

$>$ Based on the findings of the study, what vital pieces of information that can serve as useful benchmarks for teacher education curriculum?

\section{Methodology}

This study employed a qualitative research design via the questionnaire method. The printed questionnaire is composed of three open-ended items. This research instrument was content validated by three graduate students who were working on their dissertations in a State University in the Philippines at the time of the study. These are the questions in the research instrument:

$>\quad$ Think of a teacher who exemplifies effective teaching (may come from your elementary /high school or former teacher in elementary/ high school). Why do you say that he/she is an effective teacher?

$>\quad$ How would you describe the qualities that make him/her an effective teacher?

$>\quad$ Do you think that as an effective teacher, he/she possesses the knowledge in her/his subject area? If your answer is yes, why would you say that he/she is knowledgeable?

The participants of the study came from six randomly chosen public elementary schools and four randomly chosen public high schools in the City of Manila, Philippines. The "fishbowl sampling technique" was undertaken to select the 10 schools. From these 10 chosen schools, a total of 355 teachers were conveniently sampled for the study. Out of the 355 teachers, there were 89 kindergarten teachers, 166 elementary school teachers and 100 high school teachers. Of the total number of the sample, 105 were males and 250 were females. A mean of 8.5 years as length of service in the public schools was computed across all the 355 respondents.

All responses of the respondents were encoded verbatim. Since the participants were teachers who were quite well-versed in the English language, there was no need to translate their responses. As regards data analysis, questionnaire responses were subjected to thematic analysis to identify and code the significant responses in terms of the four major themes consistent with the conceptual framework of the study: personality-based traits, teaching competence-related traits content mastery and expertise and pedagogical knowledge. The resulting coded responses were categorized into core ideas and clustered into underlying themes. The resulting underlying themes with corresponding core ideas were then agreed upon by three (3) members of the faculty from two state universities in the Philippines in a one-day close-door meeting. Only those which were agreed upon by at least two judges were retained.

In addition to this process, this study adopted Bustos-Orosa's (2008) method of separating the emergent core ideas based on the thematic analysis into three types of responses, namely, general, typical, and variant (also see Heppner and Heppner, 2004). These were summarized in a table. The frequency count of each of the core ideas is depicted in the tables and is categorized as either one of the following:

$>\quad$ General' response is mentioned by the majority or more than half of the participants.

$>\quad$ Typical' response is stated by at least one-quarter to one-half of the participants. 
$>\quad$ 'Variant' response is mentioned by at least one-tenth to a quarter of the participants.

Moreover, in the data analysis, there were no significant variances identified in the responses across the three groups of respondents - the kindergarten teachers, elementary school teachers and high school teachers. Hence, the summary tables will facilitate appreciation among the readers as to how common the conceptions were among the 355 teacher-respondents of the study.Also, multiple responses were generated via the open-ended items of the questionnaire, hence, no percentage computation was done on the frequency count. The frequencies were subsequently categorized into three types of responses.

\section{Results and Discussion}

The research findings are summarized into five tables representing the five major themes and followed by discussion points in terms of the underlying themes and core ideas elicited in the study. It is significant to note that at the start of data analysis, there were four (4) a priori categories used to be consistent with the conceptual framework, the personality-based dispositions, teaching competence traits, content mastery and expertise and pedagogical knowledge. However, as the content analysis progressed, a new set of interrelated core ideas emerged and were categorized into underlying themes and eventually subsumed to one major theme.

In the presentation of the results, the data in each table are described in terms of the "type of response" instead of the actual frequency count for the core ideas to maintain the essence of the qualitative research approach employed in the study.

\subsection{Personality-Based Disposition}

On the personality related dispositions as the major theme, there were three underlying themes generated: (1) Inherent personality characteristics, (2) Good interpersonal relations, and (3) Being inspirational.

Among the inherent personality characteristics that is closely related to effective teaching as viewed by close to half of the study respondents is the teacher's demonstration of 'patience'. Having teachers catering to large-sized classes in the public schools in Manila as the study participants could have some bearing on this particular result. The call for optimum patience in teaching a large class can never be taken for granted by the teachers-in-charge. Having a good sense of humor emerged as another typical personal characteristic closely related to effective teaching. On having a good sense of humor, one high school teacher said "There were no dull moments in our class when he was my teacher in high school and we learned a lot from him."

Variant core ideas like being flexible, humble, energetic, open-minded, self-confident, sincere, honest and spiritual are inherent characteristics which could facilitate effective teaching as supported by the data in Table 1 . Possessing good moral character as well as having credibility in what the teacher is "doing" and "saying" especially inside the classroom, are two variant ideas which are embedded to the personality of an individual.

Emotional stability and steadfast adjustment to situations in the teaching-learning environment are two variant core ideas identified which focused on the affective state of the teachers. One respondent described a teacher who is emotionally stable as "calm even when stressed out". A review by Harris and Rudledge (2007) cited that one of the personality traits that is positively correlated to teacher effectiveness is emotional maturity.

Moreover, according to those surveyed, effective teachers have good interpersonal relations with their students as well as their colleagues. In particular, survey responses indicate the typical core idea that effective teachers tend to have a motherly/sisterly relationship with their students, which reinforces the notion that effective teachers generally exert their strong influence on students' wellbeing by serving as their second parents. Other typical core ideas of good communication skills, approachability, rapport with students, and working well with others were also apparent in the data. These findings are supported in the literature. For instance, according to Ellis (2004), effective teachers tend to display teacher confirmation behavior wherein teachers communicate to students that they are valuable and significant. Teachers who do exhibit this behavior have a positive effect on 
affective as well as cognitive types of learning (Ellis, 2004).

Caring or being affectionate was seen by most of the respondents as another crucial indicator of effective teaching. This finding mirrored the results of the factor analysis done by Nava (1986). It was only the "caring" attitude which emerged out of the 20 characteristics associated with teacher effectiveness involved in her analysis. Variant core ideas of being appreciative, being forgiving and being considerate or understanding could lead to the establishment of good interpersonal relations, thus fostering effective teaching. In describing the effective teacher as forgiving and motherly, one respondent said: "She has a big heart, forgiving and loving to her students".

Support for these findings can indeed be found by surveying the literature on effective teaching, which indicates that the most effective teachers are also the ones who tend to enjoy close relationships with their extended family and friends (Pajak and Blasé, 1989). It may then be inferred that their good interpersonal skills and closeness with their own kin may then translate into more loving and familial relationships with students. In the local setting, Bustos-Orosa (2008) also found out that caring and ensuring smooth interpersonal relationships are manifestations of good teaching and are considered as traits ingrained in a cultural concept Filipino anthropologists call "asal".

\section{Table 1}

Underlying Themes and Core Ideas related to Personality-based Dispositions

\begin{tabular}{|c|c|c|c|}
\hline Underlying Themes & Core Ideas & Frequency* & Type of Response \\
\hline Inherent Personal & Patient & 237 & Typical \\
\hline \multirow[t]{12}{*}{ Characteristics } & Good sense of humor & 189 & Typical \\
\hline & Flexible & 86 & Variant \\
\hline & Humble & 83 & Variant \\
\hline & Energetic & 77 & Variant \\
\hline & Self-confident & 76 & Variant \\
\hline & Open-minded & 72 & Variant \\
\hline & Sincere; honest & 70 & Variant \\
\hline & Emotionally stable & 66 & Variant \\
\hline & $\begin{array}{l}\text { Well-rounded personality; well } \\
\text { adjusted }\end{array}$ & 62 & Variant \\
\hline & Spiritual; religious; God-fearing & 59 & Variant \\
\hline & Possesses good moral character & 51 & Variant \\
\hline & Has integrity and credibility & 42 & Variant \\
\hline \multirow{8}{*}{$\begin{array}{l}\text { Good interpersonal } \\
\text { relations }\end{array}$} & Caring; affectionate & 122 & Typical \\
\hline & Approachable & 119 & Typical \\
\hline & Good communication skills & 112 & Typical \\
\hline & $\begin{array}{l}\text { Like a mother/ motherly image /sister } \\
\text { /father/brothers towards students }\end{array}$ & 97 & Typical \\
\hline & $\begin{array}{l}\text { Pleasant in dealing with others; build } \\
\text { rapport with students and colleagues }\end{array}$ & 92 & Typical \\
\hline & $\begin{array}{l}\text { Considerate; understanding especially } \\
\text { if students' limitations }\end{array}$ & 86 & Variant \\
\hline & Forgiving & 83 & Variant \\
\hline & Appreciative & 79 & Variant \\
\hline \multirow[t]{3}{*}{ Inspirational } & A role model & 156 & Typical \\
\hline & $\begin{array}{l}\text { Makes an impact to the lives of the } \\
\text { students; touches the lives of her } \\
\text { students }\end{array}$ & 67 & Variant \\
\hline & Good motivator & 53 & Variant \\
\hline
\end{tabular}

Note. *Multiple Responses

Finally, according to the respondents, effective teachers are inspirational. In expounding this third underlying theme under the personality-based disposition major theme, respondents said that effective teachers serve as role models and, for most of them, have even become the critical influence as to why the respondents 
Abulon, E. L. R.

chose to pursue a teaching career as well. Being a good motivator who pushes his/her students to maximize their potential, is also a variant core idea identified. In describing teachers as inspirational, one respondent stated:

"She touched my heart and enlightened my mind. She is a part of who I am today".

\subsection{Teaching Competence Traits}

On the second major theme "teaching competence traits", four underlying themes were identified. Having a high degree of responsibility and professionalism generated responses for almost half of the respondents (typical response type). This is concerned with the devotion and commitment to teaching. Worthy to take note the 10 respondents who specified this idea as "deep passion for teaching". "One's love for children" was mentioned by one respondent as a manifestation of the teacher's commitment to teaching profession.

Being punctual not only in coming to school but also in submitting reports and in giving feedback on students' performance is a typical core idea apparent in the data presented in Table 2. On the other hand, being organized with the materials and files in school and being respectable are the two variant core ideas that emerged from the data. "Good grooming" among teachers, is an indication of being "respectable" according to one respondent of the study.

As regards generative teaching ability, respondents identified the traits inherent in an effective teacher as: having a high level of intelligence, vision, interest in the subject matter and awareness of own strengths and weaknesses. Plans ahead of time and makes learning an enjoyable experience for children were two notable variant core ideas which all came from kindergarten teachers. According to Kourilsky et.al (1993), generative teaching ability successfully integrates four learning components that are crucial to the teaching process, namely, (1) generating a relationship between new and previous knowledge, (2) taking responsibility for one's own learning, (3) constructing meaningful conceptualizations, and (4) achieving metacognition (i.e., awareness of one's own learning processes) — all of which greatly determine teaching effectiveness.

The third underlying theme found to be related to teaching competence traits of an effective basic education teacher is the demonstration of ethical conduct. Four core ideas such as the teacher's ability to inculcate good virtues or good values to students, to exercise fairness, to know the boundaries as a teacher and to respect students, are elicited and displayed in Table 2. These core ideas were variant responses, which suggest that only a minority of respondents viewed these traits as crucial to effective teaching. However, it is significant to note how the demonstration of ethical conduct fosters effective teaching, as evidenced by these statements from two respondents:

"Even if he teaches math subject, he never forget to remind us to exhibit the good virtues like patience, obedience and kindness".

"She is an effective teacher because she did not practice favoritism in class. She was also fair in giving grades when she was my teacher."

Professional expertise and excellence emerged as the last underlying theme related to teaching competence traits as reflected in Table 2. Variant core ideas of having been teaching for a long time and having been recognized by authorities like the Philippines' Department of Education as outstanding teacher and other citations were apparent in the data gathered. The variant core idea of "long years of teaching" as conceived to be a manifestation of an effective teaching echoed one of the findings of Rice (2003) that teacher experience had a positive effect on teacher effectiveness.

\subsection{Content Mastery and Expertise}

As regards the major theme of content mastery and expertise, Table 3 revealed that most of the participants' responses could be subsumed into the underlying theme of mastery of subject matter. Within this rubric, two typical core ideas were generated such as having knowledge of the subject matter and being always ready for the 
Basic education teachers' concept of effective teaching: Inputs to teacher education curriculum

lessons. These could be manifested by "not bringing books or notes to refer to during lecture" as remarked by one of the respondents. These findings mirrored how Education Week (n.d.) exemplifies effective teachers as those possessing deep content area knowledge as well as proficiency in subject matter.

Table 2

Underlying Themes and Core Ideas related to Teaching Competence Traits

\begin{tabular}{llll}
\hline Underlying Themes & \multicolumn{1}{c}{ Core Ideas } & Frequency* & Type of Response \\
\hline High degree of & Devoted/committed/dedicated to & 167 & Typical \\
responsibility and & teaching & 154 & Typical \\
professionalism & Punctual & 47 & Variant \\
& Organized & 39 & Variant \\
Gespectable & 137 & Typical \\
ability & Intelligent; smart & 78 & Variant \\
& Has a vision & 71 & Variant \\
& Interested in the subject matter & Variant \\
& Awareness of own strength and & 53 & Variant \\
& weaknesses & & \\
& Makes learning an enjoyable & 44 & Variant \\
& experience & & Variant \\
Ethical Conduct & Plans ahead of time for every lesson & 40 & Variant \\
& Inculcates good virtues; good values & 71 & \\
& Exercises fairness; no favoritism; fair & 45 & Variant \\
& in giving grades & & Variant \\
& Aware of her boundaries as a teacher & 42 & \\
Respects students; never judge & 39 & Variant \\
Exofessional & students & & Variant \\
Excellence & Long years of teaching & 38 &
\end{tabular}

Being an expert in the content area, a basic education teacher is also expected to be a wide-reader. This is manifested by "researching from other sources to enhance lessons" as expounded by one of the respondents teaching in the high school level. Another notable statement from an elementary school teacher is that "the teacher should be 10 books away from his students". Two variant core ideas under the rubric of mastery of subject matter dealt with the clarity, accuracy and recentness of the content knowledge the teacher delivers in class as well as his easy retrieval of stock knowledge and previous readings so as to provide good illustrations to answer students' questions in class.

The other underlying theme crystallized under the major theme of content mastery and expertise is the teacher's concern for professional development and advancement. "Teachers can only teach what they know so they need to update themselves every now and then", as said by one of the respondents of the study. Three variant core ideas could exhibit his concern: by attending seminars and trainings, pursuing higher degree of education like master's degree and exerting personal effort to keep abreast with the new trends in education. One respondent illustrates this effort by saying that: "An effective teacher is one who updates himself through seminars, searches the internet or do library works". On the core idea of pursuing higher degree of education somehow contradicts the contention of Yero (n.d.) wherein he emphasized that "teachers armed with Ph.D's and Master's degrees in subject area are not guarantee of teacher quality."

\subsection{Pedagogical Knowledge}

Under the rubric of the major theme of pedagogical knowledge, the underlying themes of classroom management skills, innovativeness in teaching methods and techniques and having a student-centered teaching approach could be gleaned from the participants' responses. 
Abulon, E. L. R.

Table 3

Themes and Core Ideas related to Content Mastery and Expertise

\begin{tabular}{|c|c|c|c|}
\hline Underlying Themes & Core Ideas & Frequency* & $\begin{array}{c}\text { Type of } \\
\text { Response }\end{array}$ \\
\hline \multirow{5}{*}{$\begin{array}{l}\text { Mastery of subject } \\
\text { matter }\end{array}$} & Has Knowledge of the subject matter & 168 & Typical \\
\hline & Always ready for the lessons & 142 & Typical \\
\hline & Wide reader & 45 & Variant \\
\hline & $\begin{array}{l}\text { Delivers clear, accurate and updated } \\
\text { content knowledge }\end{array}$ & 46 & Variant \\
\hline & $\begin{array}{l}\text { Answers students' questions with good } \\
\text { illustrations }\end{array}$ & 40 & Variant \\
\hline \multirow{3}{*}{$\begin{array}{l}\text { Concern for } \\
\text { professional } \\
\text { development and } \\
\text { advancement. }\end{array}$} & $\begin{array}{l}\text { Attends seminars and trainings to hone } \\
\text { her skills / to be updated with the latest } \\
\text { trends in education }\end{array}$ & 39 & Variant \\
\hline & $\begin{array}{l}\text { Pursue master's degree / higher } \\
\text { education }\end{array}$ & 39 & Variant \\
\hline & $\begin{array}{l}\text { Exerts extra effort to be keep abreast with } \\
\text { the new innovation in education }\end{array}$ & 37 & Variant \\
\hline
\end{tabular}

As regards classroom management skills, the typical core idea of being a disciplinarian or strict so as to maintain order inside the classroom is apparent in participants' responses as exhibited in Table 4. Variant core ideas of being consistent in the implementation of class policies, being able to utilize time well and making sure that the classroom is conducive for learning, were further generated and categorized under classroom management skills.

Anent innovativeness in teaching methods and techniques, the core idea related to the teacher's ability to think and implement different methods and strategies was cited by most of the respondents. Along this core idea, one respondent expressed that an effective teacher is "flexible enough to change strategies when needed" while another respondent asserted that: "the effective teacher included challenging activities and assessment tools in his/her teaching."

"Authentic learning among the students could only be achieved if the teachers are able to relate or connect the lesson to the reality of life", a significant statement expressed by one elementary school teacher-participants of the study. And this is related to the typical core idea identified under the rubric innovativeness in teaching methods and techniques'. "Practicality" was the label given to this typical core idea by one high school-teacher participant, on the other hand. Aside from achieving authentic learning inside the classroom, the variant core ideas of 'making the discussion lively and interesting' as well as 'preparing visual aids or digitized lessons' to enhance the delivery of teaching, were apparent in the data in Table 4.

The last underlying theme under the rubric of pedagogical knowledge that Table 4 reveals is to exhibit a student-centered approach in teaching. Being such, variant ideas like allowing the students to ask questions; simplifying teaching strategies to suit the levels of the students; and considering individual differences among pupils, were apparent in the responses of the study participants. In considering individual differences among pupils, one kindergarten teacher-respondent described an effective teacher such that "She knows very well how to handle the different moods of the children in her class". One elementary school teacher-respondent, on the other hand, said that "She is attentive to the needs of the students and makes sure that she attends to these needs immediately"

These results somehow mirror what Gordon (n.d.) mentioned about factors of exceptional teachers like "motivation to teach, relationship (with students) they create and the way they structure learning" (Gordon, 2004). Moreover, the findings of Bustos-Orosa (2008) supports the above mentioned findings in relation to teacher's pedagogical knowledge: "the traits identified of good teachers all correspond with the characteristics of teachers with high instructional self-efficacy (Bustos-Orosa, 2008).” 
Basic education teachers' concept of effective teaching: Inputs to teacher education curriculum

Table 4

Underlying Themes and Core Ideas related to Pedagogical Knowledge

\begin{tabular}{|c|c|c|c|}
\hline Underlying Themes & Core Ideas & Frequency* & Type of Response \\
\hline \multirow{4}{*}{$\begin{array}{l}\text { Classroom Management } \\
\text { skills }\end{array}$} & Disciplinarian; Strict & 173 & Typical \\
\hline & Consistency in classroom rules / policies & 67 & Variant \\
\hline & Utilizes class time well; maximizes time & 56 & Variant \\
\hline & $\begin{array}{l}\text { Makes sure that the classroom is } \\
\text { conducive for learning }\end{array}$ & 47 & Variant \\
\hline \multirow{4}{*}{$\begin{array}{l}\text { Innovativeness in } \\
\text { teaching methods and } \\
\text { techniques }\end{array}$} & $\begin{array}{l}\text { Thinks and implement different } \\
\text { methods/strategies in teaching }\end{array}$ & 135 & Typical \\
\hline & $\begin{array}{l}\text { Uses practical or real situations in } \\
\text { teaching }\end{array}$ & 123 & Typical \\
\hline & $\begin{array}{l}\text { Makes discussion lively and interesting; } \\
\text { shows enthusiasm }\end{array}$ & 87 & Variant \\
\hline & $\begin{array}{l}\text { Prepares her visual aids/ digitized lessons } \\
\text { well }\end{array}$ & 54 & Variant \\
\hline \multirow[t]{3}{*}{$\begin{array}{l}\text { Student-centered } \\
\text { approach }\end{array}$} & $\begin{array}{l}\text { Allows the students to ask questions and } \\
\text { give suggestions; learns from his/students }\end{array}$ & 52 & Variant \\
\hline & $\begin{array}{l}\text { Simplifies teaching strategies to suit the } \\
\text { level of the students }\end{array}$ & 49 & Variant \\
\hline & $\begin{array}{l}\text { Considers individual differences among } \\
\text { her pupils }\end{array}$ & 41 & Variant \\
\hline
\end{tabular}

\subsection{Extension of the Self}

Out of the bulk of effective teachers' characteristics conceptualized by the 355 respondents, another major theme emerged as depicted in Table 5. Extension of the self as a major theme in this study refers to the demonstration of a teacher of his/her voluntary service to students, co-workers, to the school and even to the community. It was apparent in the data that the teachers in public schools in the City of Manila have the capacity to "walk an extra mile" despite their heavy workload and large-sized classes. The first underlying theme identified under the major theme "extension of the self" is about the teacher's generosity of his/her time, energy and knowledge. One elementary school teacher-respondent described a teacher she considered effective as: "She goes out of her way to spend extra time to sit-down with the slow readers in her class". A high school teacher-respondent shared that the teacher she considered effective was her former math teacher whom she described as a teacher who "uses almost all of her time and herself to her profession."

Table 5 also shows five variant core ideas such as undertaking remedial lessons for slow learners; going beyond of what is expected of her/him like extending working hours without pay and do home visitations to problematic students; and imparting personal wisdom to students who seek his/her advice on personal or academic problems. Relative to these core ideas, one respondent's exact description goes: "She is not only a teacher but a counselor to her students. She did not mind going to squatter's area just to visit one of her students who needs counseling”.

The other underlying theme under the rubric of 'extension of the self' is centered on the teacher's altruistic behavior - the teacher's unselfish concern towards other people. This is could be demonstrated by participating in community activities; helping the school in committee works that would redound to recognition of the school; and the willingness to mentor and assist younger teachers.

This major theme is considered the emerging critical factor of effective teaching. The conceptual framework of the study which was adapted in the Bustos-Orosa (2008) study depicted only four factors, hence, it is being proposed in this study that there should be five factors to include the "extension of the self", that contribute to effective teaching as conceptualized by basic education teachers in the public sector. 
Abulon, E. L. R.

\section{Table 5}

Underlying Themes and Core Ideas related to Extension of the Self

\begin{tabular}{|c|c|c|c|}
\hline Underlying Themes & Core Ideas & Frequency* & Type of Response \\
\hline $\begin{array}{l}\text { Generosity with one's } \\
\text { time, energy and }\end{array}$ & $\begin{array}{l}\text { Devotes time for remedial lessons for slow } \\
\text { learners }\end{array}$ & 82 & Variant \\
\hline \multirow[t]{3}{*}{ knowledge } & $\begin{array}{l}\text { Shares knowledge and experiences to } \\
\text { students }\end{array}$ & 79 & Variant \\
\hline & $\begin{array}{l}\text { Has time to listen to her students; open for } \\
\text { consultation }\end{array}$ & 76 & Variant \\
\hline & $\begin{array}{l}\text { Imparts personal wisdom not only } \\
\text { knowledge to students }\end{array}$ & 65 & Variant \\
\hline \multirow[t]{3}{*}{$\begin{array}{l}\text { Linkage with others; } \\
\text { with the community }\end{array}$} & $\begin{array}{l}\text { Participates in community activities that } \\
\text { promote learning; being a good citizen of } \\
\text { the country }\end{array}$ & 76 & Variant \\
\hline & $\begin{array}{l}\text { Makes effort for the school to be } \\
\text { recognized }\end{array}$ & 44 & Variant \\
\hline & $\begin{array}{l}\text { Willing to help other teachers; mentors } \\
\text { younger teachers }\end{array}$ & 39 & Variant \\
\hline
\end{tabular}

\section{Conclusions and Implications}

The findings of this study validate Bustos-Orosa's (2008) theoretical model on good teaching. To wit, according to Bustos-Orosa (2008), there are four critical factors that influence good teaching; these are personality-based dispositions, teaching competence traits, content mastery and expertise, and pedagogical knowledge. However, the current study is able to crystallize another critical factor which is the "extension of the self". Under this rubric, basic education teachers in the public schools believed that effective teaching further entails "selflessness" and "altruism". Hence, the current study proposes an expanded model of the critical factors not just of good teaching but more of the conceptual understanding about effective teaching. Figure 2 presents the proposed model of the critical factors of effective teaching.

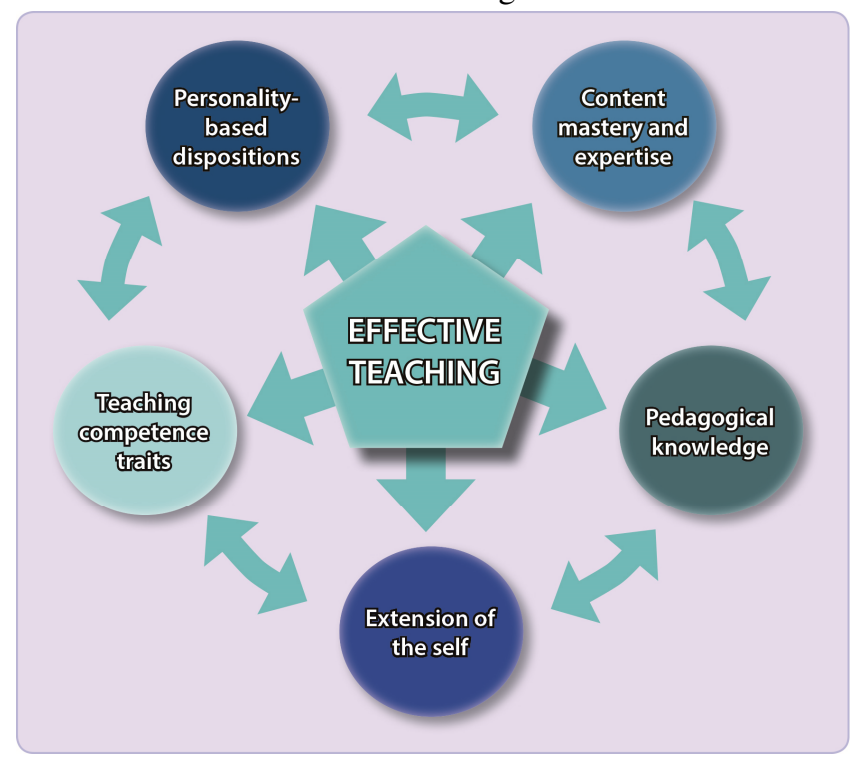

Figure 2. A Comprehensive Framework of Effective Teaching

The lack of general responses, as opposed to typical and variant type of responses, suggests that the teachers surveyed for this study tend to display variance in their conceptions of effective teaching. In other words, they tend to place importance on different factors that they view as critical to effective teaching practices. Consequently, they tend to define effective teaching differently. As a result, there was no single, predominant factor or heuristic that was identified as one upon which effective teaching is largely and/or solely contingent. 
Basic education teachers' concept of effective teaching: Inputs to teacher education curriculum

Instead, effective teaching was viewed as a confluence of various dispositions, traits, knowledge, and skill sets. This is indeed also supported by previous findings which highlight the multifaceted nature of effective teaching (e.g., Bustos-Orosa, 2008; Vaughn Kirchner, 2008; Kourilsky, Esfandiari, \& Wittrock, 1993; Pajak \& Blasé, 1989; Ellis, 2004).

Though no single, predominant factor identified, the conglomeration of conceptions about effective teaching uncovered in this study, is indeed a wellspring of useful benchmarks for curriculum planning or in re-designing the current pre-service teacher education curricular programs in the various teacher education institutions. For the different curricular offerings, especially for early childhood education, elementary education and secondary education, the typical and variant responses revealed in the study in the area of content mastery and expertise; and in pedagogical knowledge can be incorporated. For instance, demonstration of a high degree of professionalism and generative teaching ability should be part of the standards for pre-service graduates in terms of their professional competence. Under the rubric of pedagogical knowledge, innovativeness in teaching methods like the use of interactive teaching style and information communication technology (ICT) as well as highlighting the importance of authentic learning and student-centeredness, should be included in the expectations from pre-service teachers in terms of their instructional competence and efficacy.

Outlining the specific learning outcomes, like in the case of early childhood education curriculum, expectations from the pre-service teachers could include their demonstration of patience and caring attitude towards the very young population. Other personality-based dispositions such as honesty, open-mindedness, emotional maturity and flexibility could be associated in stating the expectations from the pre-service teachers in terms of their personal competence as intertwined with their responsibility to have a mastery of the content and expertise in classroom management.

Practical implications to in-service teacher education can also be gleaned from the findings. The importance of continuing education by attending training programs and even by pursuing master's degree or doctoral degree among the basic education teachers is highlighted as one of the indicators of effective teaching. Thus, the concerned agencies such as the Department of Education, the Commission on Higher Education and the Philippine Normal University as the National Center for Teacher Education could work hand in hand to address this concern. Likewise, the findings of the study with regards to the theme "extension of the self" by doing volunteer works not only for the students but also for the school, co-teachers and the community, can be encouraged among the in-service teachers by including this as another dimension for additional points in the schools' awards and incentive system.

Finally, criticisms with respect to the quality of basic education in the Philippines may also be better examined by incorporating the findings of the current study on the assessment procedures gauging teaching practices that should periodically be conducted at the national level. This will afford educators with an unfettered bird's eye view of the true current state of education in the country and whether teaching practices may actually be at fault. If this is indeed the case, targeted interventions could be conducted to redress it. Such remedial measures are crucial if the government is to achieve its main EFA 2015 goal of providing quality basic education for all Filipinos.

\subsection{Recommendation for Future Research}

Since the current study is purely qualitative in nature, this could have limited the determination of how the five major themes are independent from one another. Thus, a quantitative research approach could be undertaken with the use of rating scales as items in the research instrument that could warrant the utilization of factor analysis as the main statistical treatment of the data.

\section{References:}

Bell, T. (1962). Effective teaching: How to recognize and reward competence. New York: Exposition Press. 
Abulon, E. L. R.

Bollnow, O. (1960).On the virtues of educator. Bi-annual collection of recent German contributions to the field of educational research, 20, 98-121.

Bohn, C., Roehrig, A., \& Pressley, M. (2004). The first days of school in the classrooms of two more effective and four less effective primary-grades teachers. Elementary School Journal, 10(4), 269-287. http://dx.doi.org/10.1086/499753

Bustos-Orosa, M. A. (2008). Inquiring into Filipino teachers' conceptions of good teaching: A qualitative research study. The Asia-Pacific Education Researcher, 17(2), 157-171.

Education Week. (n.d.).Teacher Quality.Retrieved June 28, 2013, from http://www.edweek.org/ew/issues/teacher-quality/

Ellis, K. (2004). The impact of perceived teacher confirmation on receiver apprehension, motivation, and learning. Communication Education, 53(1), 1-20. http://dx.doi.org/10.1080/0363452032000135742

Ertmer, P. A. (2005). Teacher pedagogical beliefs: The final frontier in our quest for technology integration? Educational Technology Research and Development, 53(4), 25-39. http://dx.doi.org/10.1007/BF02504683

Gage, N. L. (1972). Teacher effectiveness: The search for a scientific basis. California: Pacific Book Publishers.

Gordon, G. (n.d.). Voices of highly effective teachers. Retrieved June 28, 2013, from www.gallup.com/poll/7525/Voices-Highly-Effective-Teachers.aspx

Gonzalez -Thompson, A. (1984). The relationship of teachers' conceptions of mathematics and mathematics teaching to instructional practice. Educational Studies in Mathematics, 15, 105-127. http://dx.doi.org/10.1007/BF00305892

Harris, D., \& Rudledge, S. (2007). Models and predictors of teacher effectiveness: A review of the literature with lessons from other occupations. Retrieved June 29, 2013, from http://www.teacherqualityresearch.org/models.pdf

Heppner, P., \& Heppner, M. (2004). Writing and publishing your thesis, dissertation and research: A guide for students in the helping professions. California: Thomson Brooks Cole.

Kirchner, V. J. (2008). Teacher effectiveness: The relationship of the teacher work sample to the teacher insight interview. USA: University of Louisville Press.

Klausmeier, H., \&Goodwin, W. (1970). .Learning and human abilities (4 ${ }^{\text {th }}$ ed.). New York: Harper and Row Publishers.

Kokkinos, C. M. (2007). Job stressors, personality and burnout in primary school teachers. British Journal of Educational Psychology, 77(1), 229-243. http://dx.doi.org/10.1348/000709905X90344

Kourilsky, M., Esfandiari, M., \&Wittrock, M. (1993).Generative teaching and personality characteristics of student teachers. Teaching \& Teacher Education, 12(4), 355-363. http://dx.doi.org/10.1016/0742-051X(95)00045-L

Morine-Dershimer, G., \& Kent,T. (2002).The complex nature and sources of teachers' pedagogical knowledge. Contemporary Trends and Issues in Science Education, 6(2), 21-50.

Nava, L. H. (1986). Development and validation of an instrument to measure characteristics associated with teacher effectiveness. Unpublished doctoral dissertation, University of the Philippines, Philippines.

Pajak, E., \& Blasé, J. (1989). The impact of teachers' personal lives on professional role enactment: A qualitative analysis. American Educational Research Journal, 26(2), 283-310. http://dx.doi.org/10.3102/00028312026002283

Rice, J. (2003). Teacher quality: Understanding effectiveness of teacher attributes. Retrieved July 2, 2013, from http://www.epi.org/content.cfm/books_teacher_quality

Ryans, D. (1960). Characteristics of teachers, their description, comparison and appraisal. New Delhi: Sterling Publishers Limited.

Snow, C., Barnes, W., Chandler, J., Goodman, I., \& Hemphill, L. (1991). Home and School Influences on Literacy. Cambridge: Harvard University Press.

Wynn, R. (1960). Careers in education. New York: McGraw-Hill Book Company.

Yero, J.(n.d).Teacher quality. Teachers' mind resources. Retrieved July 1, 2013, from http://www.teqachersmind.com 